\title{
Erratum to: Drivers of Durable Peace: The Role of Justice in Negotiating Civil War Termination
}

\author{
Lynn Wagner ${ }^{1,5}$ - Daniel Druckman ${ }^{2,3,4,5}$
}

\section{Erratum to: Group Decis Negot DOI 10.1007/s10726-016-9511-9}

In the original publication of the article, the reference "Fortna (2004)" is cited incorrectly both in the text and in the reference list.

In section 2, entitled "Constructing a Durable Peace Index", in the second paragraph, Fortuna (2004) should be changed to Fortna (2004). And in the reference list, Fortuna VP (2004) should be changed to Fortna VP (2004).

The online version of the original article can be found under doi:10.1007/s10726-016-9511-9.

Lynn Wagner

lynn@iisd.org

Daniel Druckman

dandruckman@yahoo.com

1 International Institute for Sustainable Development, Winnipeg, Canada

2 George Mason University, Fairfax, VA, USA

3 Macquarie University, Sydney, Australia

4 University of Queensland, Brisbane, Australia

5 Uppsala University, Uppsala, Sweden 